tolento

\title{
Increased Revenues in Beef Cattle Business in Hamlet I Kelambir V Village in Hamparan Perak Sub-District Deli Serdang Regency
}

\author{
Julia Marisa and Sukma Aditya Sitepu \\ Faculty of Agriculture, University of Pembangunan Panca Budi
}

\begin{abstract}
This community service aims to introduce revenue analytics in beef cattle business to breeders in order to know the amount of their income in every scale of livestock ownership level in Hamlet I, Kelambir Village, Hamparan Perak Sub-District, Deli Serdang Regency. This activity was expected to improve the ability and increase the knowledge of beef cattle breeders to do self-analysis on how to separate accepted and cost components to be incurred in one period of care. Thus, it would be easier for the breeders to calculate the total income in one period of beef cattle breeding which will improve their welfare. The impact brought from this program was that a number of breeders have understood about revenue analytics and started to calculate the total income they have had. Therefore, they can learn to make the production cost of their business efficient which leads to an increased revenues.
\end{abstract}

Keywords: Beef Cattle, Production, Revenue

Abstrak. Tujuan dari pelaksanan pengabdian kepada masyarakat ini adalah melakukan pengenalan kepada peternak tentang analisis pendapatan usaha ternak sapi potong untuk mengetahui besarnya pendapatan peternak sapi potong pada berbagai skala tingkat kepemilikan ternak di Dusun I Desa Kelambir V Kecamatan Hamparan Perak Kabupaten Deli Serdang. Pelaksanaan pengabdian masyarakat ini diharapkan dapat meningkatkan kemampuan dan pengetahuan peternak sapi potong di Dusun I Desa Kelambir V Kecamatan Hamparan Perak Kabupaten Deli Serdang untuk menganalisis sendiri tentang bagaimana memisahkan antara komponen penerimaan dan komponen biaya yang akan dikeluarkan dalam satu periode pemeliharaan sehingga memudahkan mereka untuk dapat menghitung seberapa besar total pendapatan yang mereka hasilkan dalam satu periode pemeliharaan ternak sapi potong, yang akhirnya meningkatkan kesejahteraan peternak tersebut. Adapun hasil yang diperoleh dari pelaksanaan program ini terlihat beberapa peternak sudah memahami analisis pendapatan usaha ternak sapi potong dan mulai memperhitungkan

*Corresponding author at: Jalan. Gatot Subroto KM 4.5 Medan 20122, Indonesia

E-mail address: juliamarisa@pancabudi.ac.id 
berapa pendapatan yang selama ini telah mereka peroleh sehingga mereka belajar mengefisiensikan biaya produksi usaha mereka agar pendapatan yang diperoleh meningkat.

Kata Kunci: Pendapatan, Produksi, Sapi Potong

Received 6 November 2017 | Revised 10 January 2018 | Accepted 9 March 2018

\section{Introduction}

Hamlet I of Kelambir V Village in Hamparan Perak Sub-District, Deli Serdang Regency is a village where most of the people work as labours. Many villagers in that area have business in beef cattle. Livestock raising system used in this village is a partial system in which livestock is kept in each owner's byre. In other words, the activity of raising beef cattle is not done together. The raising system mostly applied is a semi-intensive; livestock is only taken care at night in the byre while in the morning they are shepherded around the farms in that area.

The way stock farmers consider beef cattle as a side business and run the business in a semi-intensive way were some of the problems found in Hamlet I Kelambir V Village, Hamparan Perak Sub-District, Deli Serdang Regency. Other problemsincluded the incapability to calculate overheads and income hence no financial records available, yet there has never been a training or workshop held to tackle these problems. Furthermore, the stakeholders themselves were less motivated to analyze the business income.

Giving understanding about the importance of doing income analytics in beef cattle business was the main solution for these problems. Next solution was to conduct a training for doing income analytics and making a financial report for the business itself. The outcomes expected was that the respondents gain knowledge from academicians about how to calculate both production cost and income, able to make a financial report for the business. By acknowledging cost efficiency and resources used, the farmers would be able to increase productivity and beef cattle production. The villagers' income would also increase along with the rise of productivity and cattle produced. Moreover, this activity would form a good synergy between the university and the villagers in the form of community service.

\section{Method}

The community service conducted was by approaching the stock farmers and holding a seminar and discussion. The seminar was first given and continued with a discussion. The topics given were about the potential of beef cattle in Indonesia and how it might boost the economy of the community. Other than that the calculation of the costs and income in the beef cattle business, as well as a guidance to make a financial report, was also presented. After the materials were given, 
the respondents directly calculated their overheads and income, and also made the financial report for their businesses.

\section{Working Procedures}

Direct observation with interview approach was done as a part of the activity. Problems found from the observation and socialization were reviewed, and solutions were determined. Next, the implementations were ordered in terms of priority. Finally, this community service was conducted by providing socialization and direct practice. After the whole activity had been completed, evaluation was conducted by having follow-up observations to the business financial report made in Hamlet I of Kelambir V Village in Hamparan Perak Sub-District, Deli Serdang Regency.

\section{Results and Discussion}

After the community service was conducted on 14 June 2017, post-observation was done on 16 June 2017. Following were the results obtained:

1. Based on the post-observation, the stock farmers have started to consider and calculate the total operational cost in detail, including the fixed variable and cost for the entire business duration to know the total income earned.

2. Respondents stated that they have started to pay more attention to the income analytics of their beef cattle business.

3. Respondents have understood the importance of analyzing the total income of beef cattle business and how they can learn to make the operational cost efficient to increase their profit in the business.

4. Respondents gained knowledge about how to calculate the operational cost and income, also how to make a financial report for the beef cattle business.

5. Respondents are trying to make a financial report for their business.

Prior to the community service, the stock farmers did not calculate the overheads and income from the beef cattle business. After the community service was held, they have considered and calculated the costs incurred in detail, including the fixed variables and costs. They also have realized the importance of beef cattle business income analytics in order to know the total income earned; thus, effective planning to operational cost can be done to increase the farmers' income.

Follow-up socialization was needed to improve the knowledge and understanding of business analytics in the beef cattle industry in Hamlet I, Kelambir V Village, Hamparan Perak Sub-District, Deli Serdang Regency. The aims were to increase awareness towards the 
importance of business analytics in determining the effectiveness of production cost and the profitability of beef cattle business [1].

By having a good understanding of business analytics, the farmers can manage their income well in accordance with the effectiveness of production cost used [2]. In addition to business analysis, training forcultivation business and marketing of beef cattle were needed to increase production and profitability resulting in increased income and improved welfare of the farmers [3].

The farmers still encountered difficulties in making a good report due to the short duration of training. Therefore, regular guidance was needed until the farmers become skilled in organizing and analyzing their beef cattle business.

\section{Conclusion}

Some real impacts in income analytics and financial reports in beef cattle business have been seen after the community service inHamlet I, Kelambir V Village, Hamparan Perak Sub-District, Deli Serdang Regency. The stock farmers have gained a better understanding and knowledge of overheads and income calculation as well as doing financial report in their beef cattle business. However, socializationabout related skills needed in Hamlet I, Kelambir V Village, Hamparan Perak Sub-District, Deli Serdang Regencywill be a good improvement as the people are open, willing, and eligible towards improvement from external parties.

\section{References}

[1] Prawirokusumo, Y. B., 1991. Ilmu Usahatani. BPFE, Yogyakarta.

[2] Aritonang, D. 1993. Perencanaan dan Pengelolaan Usaha. Penebar Swadaya, Jakarta.

[3] Soekartawi. 2002. Prinsip Dasar Ekonomi Pertanian Teori dan Aplikasi. Jakarta: PT. Raja Grafindo.

[4] Cyrilla, L. and Ismail. A., 1998. Usaha Peternakan. Diktat Kuliah. Jurusan Sosial Ekonomi. Fakultas Peternakan. Institut Pertanian Bogor, Bogor.

[5] Direktorat Jenderal Peternakan. 2007. Statistik Peternakan. Direktorat Jenderal Peternakan, Jakarta.

[6] Fauzia, L., and H. Tampubolon., 1991. Pengaruh Keadaan Sosial Ekonomi Petani Terhadap Keputusan Petani Dalam Penggunaan Sarana Produksi. Universitas Sumatera Utara Press, Medan.

[7] Hernanto, F. 1996. Ilmu Usahatani. Penebar Swadaya. Jakarta.

[8] Saleh, E., Yunilas and Yanda. 2006. Analisis Pendapatan Peternak Sapi Potong di Kecamatan Hamparan Perak Kabupaten Deli Serdang. Jurnal Agribisnis Peternakan No 1 Volume 2 Soehadji. 1992.

[9] Tohir, K. A., 1991. Seuntai Pengetahuan Usahatani Indonesia. Rineka Cipta, Jakarta. 